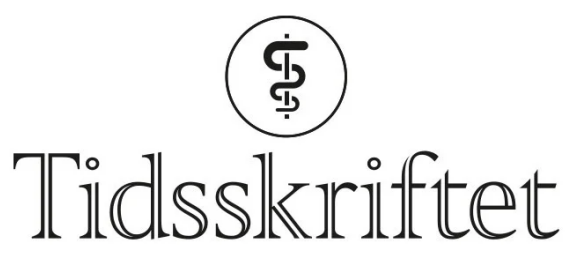

DEN NORSKE LEGEFORENING

\title{
Kjærlighetserklæring fra en bestemor
}

ANMELDELSER

EILI SPONHEIM

Pensjonert barne- og ungdomspsykiater

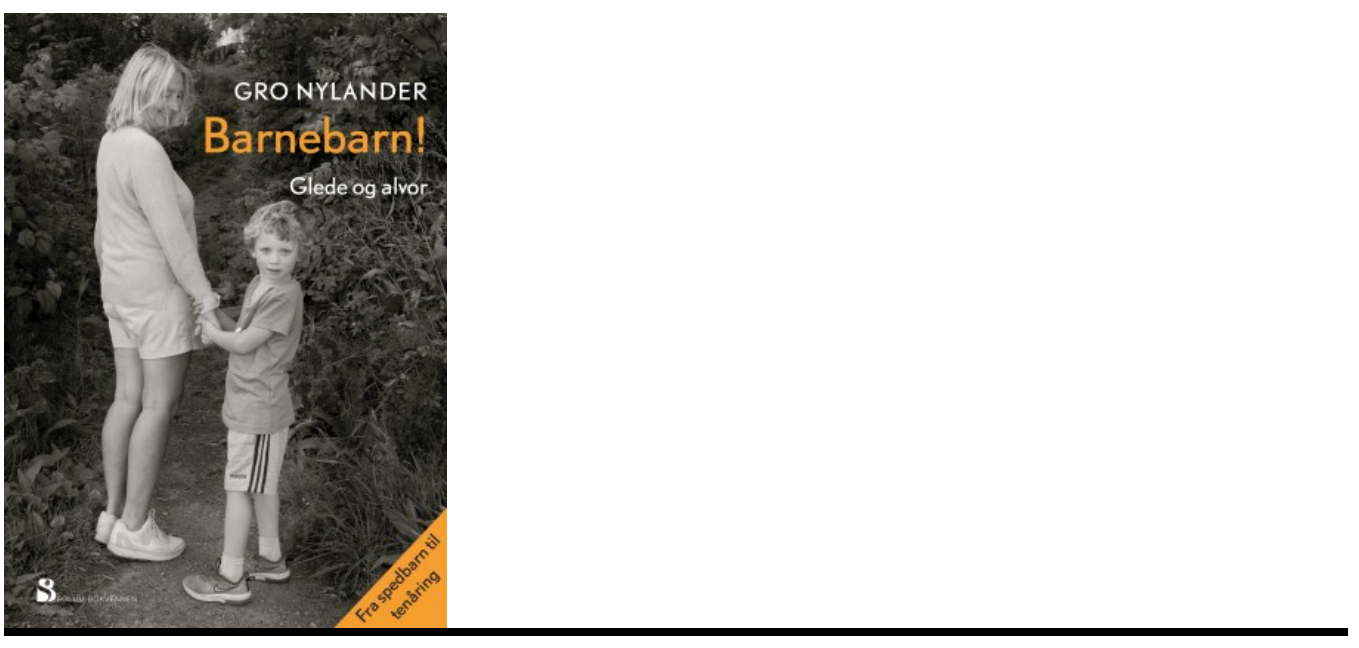

Gro Nylander

Barnebarn!

Glede og alvor. 263 s, ill. Oslo: Solum bokvennen, 2019. Pris NOK 399

ISBN 978-82-7488-915-6

Målgruppen er alle besteforeldre uansett bakgrunn, men boka kan med fordel leses både av leger og foreldre flest. Her deles mange gode råd og eksempler, ikke minst om hvordan man kan snu negative utsagn om til noe positivt. Det er alt fra råd om barnevogner og viktigheten av ansikt til ansikt-kontakt til begrensning i bruk av mobiltelefoner og andre tidstyver. Rådene er i hovedsak kvalitetssikret med referanser til forskning og annen litteratur, ikke minst forfatterens egen.

Boka er kronologisk bygd opp fra nyheten om det kommende barnet til ungdomstiden. Korte kapitler og mange underavsnitt, alle med gode overskrifter, gjør boken lett å lese, manøvrere rundt i og slå opp i. Bildene er vakre og mange, og det er til og med fine tegninger laget av et barnebarn. 
Dette er en raus bok hvor forfatteren byr på seg selv. Og hennes erfaring er omfattende. Som lege og gynekolog, Norges ammespesialist, forsker og formidler med interesse for blant annet psykologi og miljøsak, er hun ingen gjennomsnittsbestemor, men hun har den samme entusiasmen de aller fleste besteforeldre kan kjenne seg igjen i og føle slektskap til. Med sin solide bakgrunn og sitt mot kan hun utfordre politisk korrekthet om barnehagestart og fordeling av foreldrekvoter, det siste godt forankret i et glødende arbeid for amming.

En viss konflikt er det allikevel i underkommuniseringen av viktigheten av også å hjelpe et barn inn i gode rutiner det første leveåret, noe som kan oppfattes som en motsetning til å få til amming. Ikke alle får til det, til tross for iherdig innsats - med og uten besteforeldre. Ingen burde føle at de kommer til kort av den grunn. Temaer om barnebarn som er funksjonshemmet eller dør, er også med i boka, men utgjør bare en liten del. Her kunne nok forfatteren ha gitt mer.

Gro Nylander legger lista høyt, men slik bør det også være. Barnebarn er fremtiden. Det brenner forfatteren for i en slik grad at det smitter. Miljøsaken kommer på kjøpet. Vi i besteforeldregenerasjonen blir heiet ut av godstolen - og godt er det.

Publisert: 7. september 2020. Tidsskr Nor Legeforen. DOI: 10.4045/tidsskr.20.0481

(C) Tidsskrift for Den norske legeforening 2023. Lastet ned fra tidsskriftet.no 26. april 2023. 